\title{
Analisis Forman Frekuensi pada Suara Manusia dengan Menggunakan Linear Prediction
}

\author{
IRMA AMELIA DEWI, MUHAMMAD ICHWAN, SALMA SILFIANA
}

Program Studi Informatika Institut Teknologi Nasional Bandung

Email: irma_amelia@itenas.ac.id

Received 10 Maret 2020| Revised 25 April 2020 | Accepted 28 Mei 2020

\begin{abstract}
ABSTRAK
Suara manusia merupakan natural language sebagai salah satu gaya interaksi dengan komputer. Manusia mempunyai ragam suara yang berbeda, dapat dilihat dari formant, pitch dan volume suara. Masukan perintah suara yang baik bagi komputer dibutuhkan proses pencarian kualitas suara berdasarkan forman frekuensi. Pada penelitian ini tahapan proses diawali dengan pre-processing yaitu preemphasis, frame blocking dan windowing kemudian dilanjutkan pencarian nilai forman menggunakan Linear Prediction. Hasil nilai forman yang didapatkan dicocokan dengan nilai forman data latih yang berada pada database. Terdapat 2700 data suara uji dengan durasi perekaman suara dilakukan selama 1 detik. Berdasarkan hasil pengujian nilai forman yang diperoleh untuk FO kisaran 0-423, nilai forman F1 kisaran 572-1678, nilai forman F2 kisaran 1536-2583, nilai forman F3 kisaran 2676-3384, nilai forman F4 kisaran 3519-4947.
\end{abstract}

Kata kunci: Forman, Frekuensi, Pitch , Linear Prediction

\begin{abstract}
Human voice is a natural language as a style of interaction with computers. Humans have a variety of sounds can be seen from the formant, pitch and volume. Entering voice commands that are good for the computer requires the search for sound quality based on formant frequencies. In this study, the process stages begin pre-emphasis, frame blocking and windowing for noise reduction and searching formant values using Linear Prediction. The formant value obtained is matched with the formant value of the training data in database. There are 2700 test sound data with recording duration is 1 second. Based on test results obtained formant values for FO range of 0-423, value range 572-1678 formants F1, F2 formant values range from 1536 to 2583, the value of the range of 2676-3384 formant F3, F4 formant values of the range of 3519-4947.
\end{abstract}

Keywords: Formant, Frequency, Pitch, Linear prediction 


\section{PENDAHULUAN}

Suara manusia merupakan sinyal multidimensi yang membawa berbagai jenis informasi seperti frekuensi dasar (Pitch), energi dan durasi pengucapan. Sinyal suara juga dapat menyampaikan banyak informasi tentang pembicara seperti jenis kelamin, usia, identitas individu dan aspek lainnya (Devi , Erwin, \& Surbakti, 2017). Pitch (F0) merupakan nilai perbedaan frekuensi suara yang disebabkan oleh membuka dan menutupnya pita suara (Bhaskoro \& D, 2012).

Setiap manusia memiliki keragaman jenis suara, walaupun terkadang terdapat kemiripan namun secara parameter dari bentuk suara tersebut berbeda-beda. Secara persepsi fisik manusia terhadap suara memiliki beberapa parameter, yaitu formant, jenis suara, pitch, timbre dan volume. Berdasarkan persepsi fisik, manusia dapat dengan mudah mengidentifikasi gender dari jenis suara tersebut. Salah satu parameter persepsi fisik yang cukup berpengaruh adalah Forman (Bhaskoro \& D, 2012). Forman merupakan frekuensi resonansi alami yang dihasilkan dari pelbagai rongga mulut dan tenggorokan, output yang dihasilkan tergantung pada bentuk dan ukurannya. Sehingga forman menghasilkan 3 jenis formant yaitu F1, F2, dan F3.

Suara atau ucapan manusia dapat dijadikan salah satu cara untuk berinteraksi antara manusia dengan komputer. Setiap suara yang dimiliki manusia mempunyai keragaman bentuk yang berbeda-beda (Permana, Nurhasanah, \& Zulkarnain, 2018) (Nurhasanah, Zulkarnain, \& Permatasari, 2017). Perbedaan tersebut bisa dilihat dari jenis kelamin , vocal range ,usia dan ragam suara yang berbeda. Ragam suara yang berbeda bisa disebabkan karena formant , pitch dan volume suara setiap orang yang berbeda (Umar, Sunardi , \& Gustafi, 2019). Pada penelitian ini fokus bagaimana menganalisa kualitas frekuensi formant pada suara pembicara dalam pengucapan angka dengan menggunakan Linear prediction untuk mendapatkan nilai formant yang kemudian dicocokan dengan formant yang berada pada data latih menggunakan metode KNN. Dengan hasil yang dikeluarkan oleh sistem adalah hasil kualitas suara.

\section{METODE PENELITIAN}

Masukan pada sistem ini adalah nilai sinyal suara yang didapat dari masukan suara data latih ataupun data uji dengan format suara dalam bentuk .wav yang akan dilakukan proses preprocessing dan pencarian nilai formant pada suara yang sudah di-inputkan seperti pada Gambar 1. Kedepannya penelitian ini akan digunakan untuk menentukan kualitas suara manusia berdasarkan nilai forman sebagai inputan dari perintah suara ke sistem digital.

Pada sistem terdapat pencarian untuk mencari file data uji yang sudah dilakukan perekaman sebelumnya dengan melakukan proses load suara pada aplikasi yang sudah disiapkan. Sistem dapat melakukan proses menghilangkan gangguan suara yang dilakukan di bagian Preprocessing dan dilanjutkan dengan dilakukan pencarian nilai forman. Nilai forman yang didapatkan dari hasil proses Linear Predicition. Pada Gambar 2 merupakan tahapan pada proses pre-processing sinyal suara. 
Analisis Forman Frekuensi pada Suara Manusia dengan Menggunakan Linear Prediction

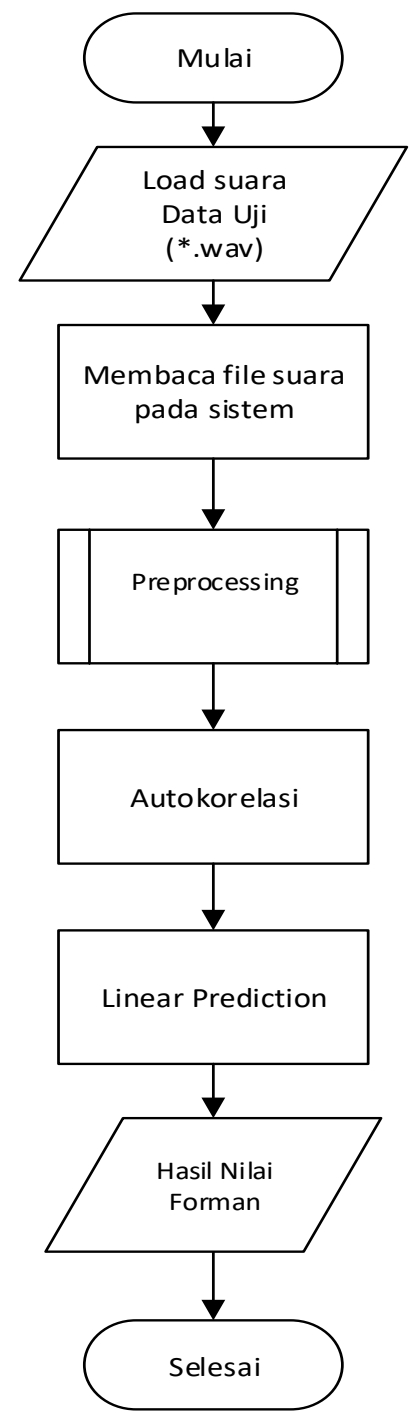

Gambar 1. Flowchart Sistem Keseluruhan

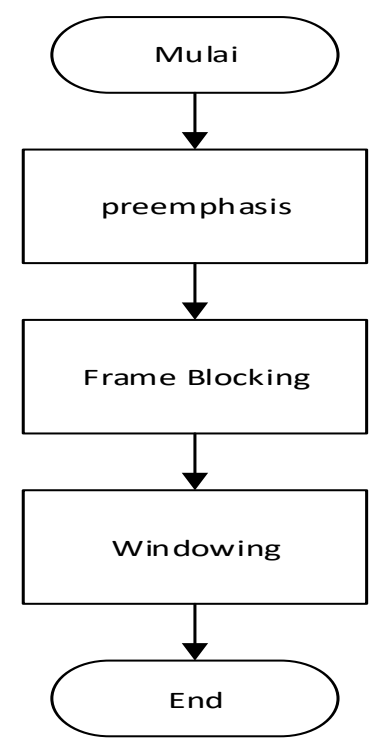

Gambar 2. Tahap Pre-Processing Sinyal Suara

MIND - 41 


\subsection{Akusisi Data}

Langkah awal yang dilakukan dalam penelitian ini adalah melakukan akuisisi data. Proses akuisisi ini suara dilakukan berdasarkan data sinyal suara yang diperoleh dengan cara merekam suara untuk data latih dan data uji menggunakan mikrofon yang memiliki spesifikasi dan dengan ruang tertentu untuk menekan adanya noise. (Dewi, Zulkarnain, \& Aprilia, 2018). Frekuensi samping yang digunakan adalah frekuensi standar $16.000 \mathrm{~Hz}$ dengan format .wav, 16 bit/sample dan menggunakan channel mono. Durasi rekaman pada proses latih dan uji adalah 1 detik.

Persamaan (1) adalah rumus untuk mencari akuisisi data pada proses pengambilan sampling

$$
X=F S x d t(\operatorname{detik}) x\left(\frac{b i t}{8}\right) x j
$$

Keterangan :

$\mathrm{X}$ :Data sampling sinyal

Fs :Frekuensi sampling

dt :Durasi rekaman (detik)

bit :Jumlah bit resolusi

j $\quad: 1$

Perhitungan pada proses akusisi data untuk pengambilan sampling adalah :

$$
X=16000 \times 1 \times\left(\frac{16}{8}\right) \times 1=32000 \text { byte }
$$

Persamaan (2) adalah rumus untuk menghitung sample rate

$$
\text { Sample rate }=\frac{F s}{T s}
$$

Keterangan :

Fs : Frekuensi Sampling

Ts : Durasi

Perhitungan untuk mendapatkan sample rate adalah :

$$
\text { Sample Rate }=\frac{32000}{1}=32000 \mathrm{~Hz}
$$

Persamaan (3) adalah rumus untuk menghitung sample point

$$
\text { Sample point }=\text { sample rate } * \text { waktu ambil data }
$$

Untuk mendapatkan sample point adalah :

$$
\text { Sample point }=32000 \times 0.01=320 \text { sample point }
$$

Untuk contoh perhitungan digunakan contoh data nilai suara sebanyak 8 angka dari salah satu sample suara. Data tersebut adalah $(0.0057,0.0033,0.0040,0.0039,0.0016,-0.0014$, $0.0059,0.0055)$ 


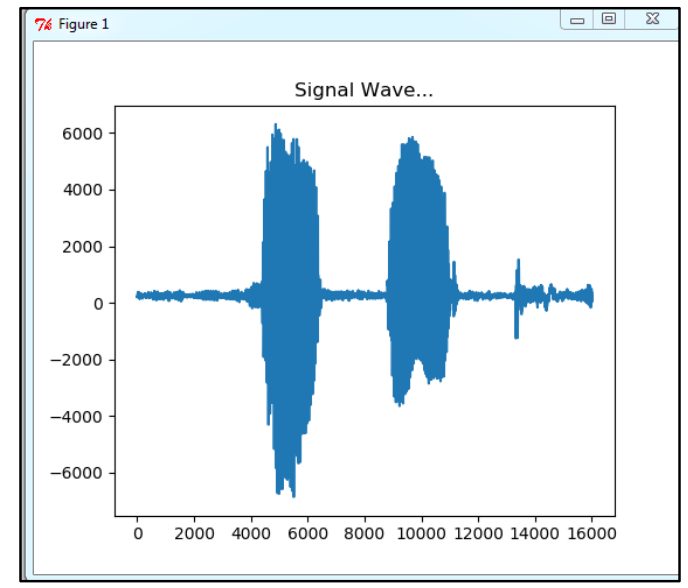

Gambar 3. Sinyal Suara Asli

Gambar 2. adalah gambar sinyal suara asli yang belum dilakukan pemfiilteran dan perubahan sinyal suara.

\subsection{Pre-emphasize}

Pre-emphasize merupakan tahapan awal yang digunakan untuk meratakan sinyal spectra/dan membuat sinyal rentan terhadap efek presisi dalam pemrosesan sinyal. Biasanya pada metode preemphasize digunakan filter yang bernama High Pass Filter berorde satu. High Pass Filter merupakan penapis yang meloloskan/meneruskan sinyal yang memiliki frekuensi tinggi dan menekan frekuensi yang lebih rendah daripada frekuensi cutoff (frekuensi kerja dari suatu sinyal)

$$
y[n]=s[n]-a s[n-1]
$$

Keterangan:

$\mathrm{y}[\mathrm{n}]$ :Sinyal hasil pre-emphasis filter

$\mathrm{s}[\mathrm{n}]$ :Sinyal sebelum pre-emphasis filter

$a$ :Merupakan konstanta filter preemphasis,

biasanya bernilai 0,97

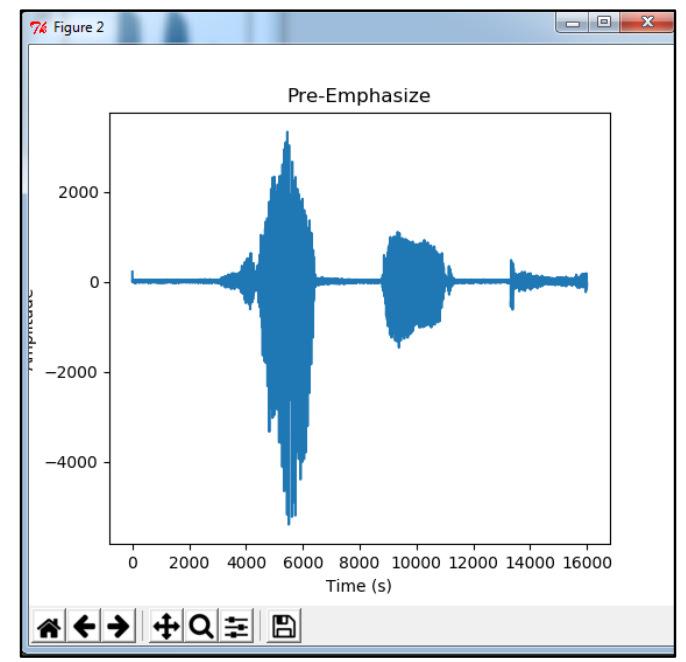

Gambar 4. Sinyal Setelah Dilakukan Proses Preemphasis 
Hasil sinyal pre-emphasize pada data ke 0 ( Y $[0]$ ) sama dengan nilai sinyal sebelum proses pre-emphasize ( $\mathrm{S}[0]$ ) karena belum terjadi proses pre-emphasize sehingga belum ada perubahan nilai. Diteruskan dengan perhitungan nilai yang selanjutnya dimana $\mathrm{Y}$ dan $\mathrm{S}$ akan mengitung data angka ke 1

$\mathrm{Y} 1=\mathrm{s}[1]-\mathrm{a} \mathrm{s}[1-1]$

$\mathrm{Y} 1=0,0033-(0,97 * s[0])$

$\mathrm{Y} 1=0,0033-(0,97 * 0,0057)$

$Y 1=-0,0022$

Keterangan :

Y1 = sinyal hasil preemphasis yang pertama

$\mathrm{s}[1]$ = data yang ke 1 yaitu 0,0033 sesuai dengan data sample suara.

$\mathrm{a}=$ merupakan konstanta filter preemphasis, biasanya bernilai 0,97

$\mathrm{s}[1-1]=$ diambil dari $\mathrm{s}[\mathrm{n}-1]$ yang dimana $\mathrm{n}$ adalah urutan data.

$\mathrm{s}[0]=$ data hasil preemphasis yang ke $0(\mathrm{~s}[0]$ sama dengan $\mathrm{y}[0])$.

Berikutnya dicari nilai data sinyal baru yang diperoleh dari penambahan data sinyal sebelum proses pre-emphasis dengan data hasil pre-emphasis menggunakan persamaan berikut:

$\mathrm{Nn}=\mathrm{Nn}+\mathrm{Yn}$

NO $=0,0057+0,0057=0,0114$

Keterangan :

$\mathrm{Nn}=$ Data sinyal baru hasil preemphasis

$\mathrm{Nn}=$ Nilai sinyal sebelum dilakukan preemphasis

$\mathrm{Yn}=$ Data hasil preemphasis sebelumnya

Begitu juga dengan ketujuh data yang lainnya, sehingga didapatkan nilai sinyal setelah preemphasis adalah : $(0.0114,0.0011,0.0072,0.0077,0.0053,0.0001,-0.0046,-0.0002)$

\subsection{Frame Blocking}

Pada proses frame blocking sinya suara dibagi menjadi beberapa frame untuk memudahkan dalam proses analisa suara. Pada pengolahan sinya suara dibutuhkan sinyal yang memiliki parameter yang tetap (berubah dengan lambat) terhadap waktu (time invariant). Output dari proses frame blocking ini akan menghasilkan sinyal suara yang dianggap tidak berubah terhadap waktu (Dewi, Zulkarnain, \& Aprilia, 2018) (Rabiner \& Juang, 1993).

$$
\begin{gathered}
x_{l} n=\tilde{s} M l+n, \quad n=0,1, \ldots, N-1, \\
l=0,1, \ldots, l-1
\end{gathered}
$$

Keterangan :

Xi n : Sinyal ke-n frame blocking

$M$ : jarak antar frame

$\mathrm{N}$ : ukuran frame (frame size)

I : Frame 


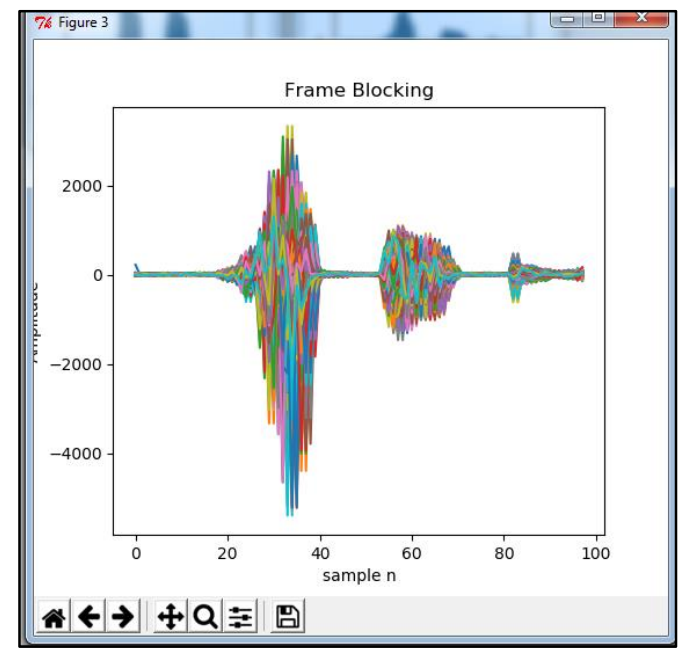

Gambar 5. Sinyal Setelah Dilakukan Proses Frame Blocking

Diketahui nilai sinyal setelah preemphasis adalah : $(0.0114,0.0011,0.0072,0.0077,0.0053$, $0.0001,-0.0046,-0.0002)$

$\mathrm{N}=$ Frekuensi Sampling $*$ sample dalam satuan detik

$\mathrm{N}=16.000 * 0,02=320$ sample

Dan akan didapatkan Overlappingframe (M) sebagai berikut

$M=$ Frekuensi Sampling * sample dalam satuan detik

$M=16.000 * 0,01=160$

$x(n)=y(M+n)$

Keterangan :

$x(n) \quad=$ hasil frame blockingke $-n$

$\mathrm{y} \quad=$ nilai suara yang sudah dilakukan proses preemphasis

$\mathrm{M} \quad$ = Overlappingframe

$\mathrm{n} \quad=$ data ke-n

$x(n)=y(M+n)$

$x(0)=y(M+0)$

$x(0)=0.0114(M+0)$

$x(0)=0.0114(160+0)=1.824 \mathrm{~Hz}$

Sehingga didapatkan nilai sinyal setelah Frame Blocking adalah : $(1.824,1.1771,1.1664$, $1.2551,0.8692,0.0165,-0,7363,-0.0334)$

\section{$2.4 \quad$ Windowing}

Setelah proses frame blocking selesai dilakukan, tahapan berikutnya adalah proses windowing. Windowing adalah proses mengubah sinyal pada awal dan akhir setiap frame bernilai nol. Hal ini bertujuan untuk menghilangkan diskontinyuitas sinyal pada awal dan akhir frame. Hamming Window merupakan model yang sering digunakan karena Hamming Window menghasilkan noise yang tidak terlalu besar (Dewi, Zulkarnain, \& Aprilia, 2018). Untuk menghitung nilai hasil windowing digunakan Persamaan (6): 


$$
w(n)=0.54-0.46 \cos \left(\frac{2 \pi n}{N-1}\right)
$$

Keterangan :

$\mathrm{w}(\mathrm{n})=$ hasil nilai Windowing yang ke- $\mathrm{n}$

$\Pi=3,14$

$\mathrm{N}=$ Jumlah sample pada masing- masing frame

$\mathrm{n} \quad=0,1,2,3, \ldots \mathrm{N}-1$

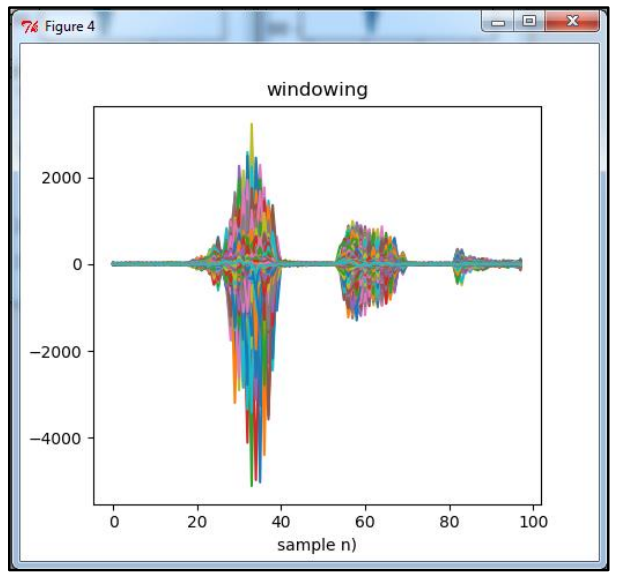

\section{Gambar 6. Sinyal Setelah Dilakukan Proses Windowing}

Diketahui nilai sinyal setelah Frame Blocking adalah : $(1.824,1.1771,1.1664,1.2551,0.8692$, $0.0165,-0,7363,-0.0334)$ dengan nilai $\mathrm{N}=320$ dari perhitungan $\mathrm{N}$ pada bagian frame blocking sebelumnya. Penyelesaian window w(n):

$$
\begin{gathered}
w(n)=0.54-0.46 \cos \left(\frac{2 \pi n}{N-1}\right) \\
w(0)=0.54-0.46 \cos \left(\frac{2 \times 3.14 \times 0}{320-1}\right) \\
w(0)=0.008 \cos \frac{0}{319} \\
w(0)=0.008 \cos 0 \\
w(0)=0.008 \times 1=0.08
\end{gathered}
$$

Untuk data frame blockingyang digunakan adalah : $(1.824,1.1771,1.1664,1.2551,0.8692$, $0.0165,-0,7363,-0.0334)$

sehingga :

$\mathrm{w}(\mathrm{o})=$ Nilai Frame Blocking $*$ hasil $\mathrm{w}(0)$

$w(0)=1.824 * 0.08$

$\mathrm{w}(0)=0.14592$

Maka , Hasil dari windowing dari keseluruhan nilai yaitu $(0.14592,0.094168,0.093312$ $, 0.100408,0.069536,0.00132,-0.058936,-0.002672$ )

\subsection{Linear Prediction}

Tahap untuk mencari nilai formant diambil data masukan berupa nilai yang dihasilkan setelah proses windowing. Tahap selanjutnya dari proses windowing adalah proses analisis autokorelasi (autocorrelation analysis). 


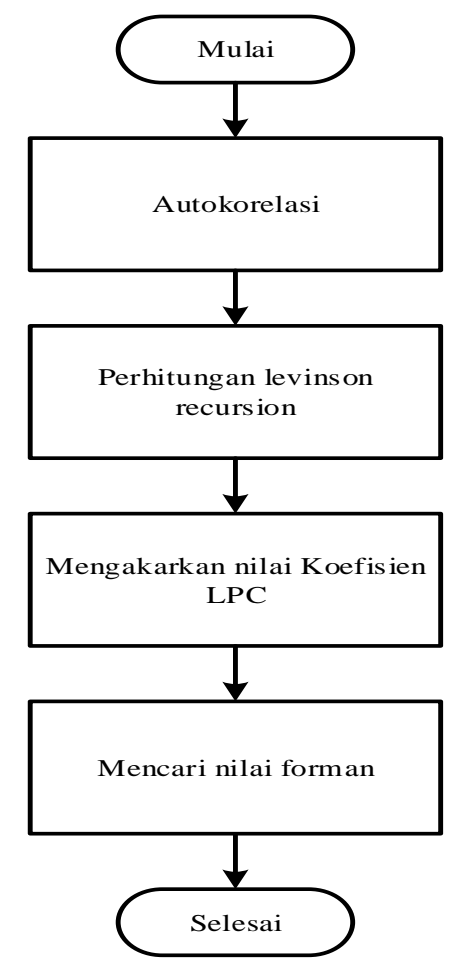

Gambar 7. Flowchart Linear Prediction

Untuk mencari nilai Autocorrelation dapat menggunakan Persamaan 7

$$
r_{l}(m)=\sum_{n=0}^{N-i-m} \tilde{x}_{l}(n) \cdot \tilde{x}_{l}(n+m), m=0,1, \ldots, p
$$

Dimana :

$r_{l}(m)$ adalah Hasil sinyal autokorelasi

$\tilde{x}_{l}(n)$ adalah Hasil sinyal windowing ke-n

Jika data hasil windowing sampel data latih adalah $(0.14592,0.094168,0.093312,0.100408$, $0.069536,0.00132,-0.058936,-0.002672)$ maka nilai autokorelasinya

$$
\begin{aligned}
m(1) & =\tilde{x}_{l}(1) \tilde{x}_{l}(1+1) \\
& =(0.14592) \tilde{x}_{l}(2) \\
& =(0.14592)(0.094168) \\
& =1.374 \times 10^{-2}
\end{aligned}
$$

Maka, Hasil dari keseluruhan nilai yaitu $\left(1.374 \times 10^{-2}, 0.946 \times 10^{-2}, 0.012 \times 10^{-2}, 0.027 \times 10^{-}\right.$ $\left.{ }^{2}\right)$. sehingga untuk mendapatkan nilai autokorelasi dilakukan dengan menambahkan semua hasil perhitungan sebelumnya

$$
\begin{aligned}
r_{i}(m) & =1.374 \times 10^{-2}+0.946 \times 10^{-2}+0.012 \times 10^{-2}+0.027 \times 10^{-2} \\
& =2.359 \times 10^{-2}
\end{aligned}
$$

Maka hasil dari nilai akhir dari nilai analisis autokorelasi adalah 2.359 × 10-2 .Langkah selanjutnya adalah melakukan perhitungan Levinson Durbin pada nilai autokorelasi yang didapat, seperti terlihat pada Persamaan 8 untuk mendapatkan koefisien Ipc A(z).

Levinson Durbin : 


$$
\left[\begin{array}{cccc}
R[0] & R[1] & R[2] & R[p] \\
R[1] & R[0] & R[1] & R[p-1] \\
R[2] & R[1] & R[0] & R[p-2] \\
R[p] & R[p-1] & R[p-2] & R[0]
\end{array}\right]\left[\begin{array}{l}
a 1 \\
a 2 \\
a 3 \\
a p
\end{array}\right]=\left[\begin{array}{c}
R(1) \\
R(2) \\
R(3) \\
R(p)
\end{array}\right]
$$

Dengan solusi pemecahan terlihat pada Persamaan 9 sampai dengan Persamaan 15.

$$
\begin{gathered}
E^{(0)}=R(0) \\
k_{(i)}=R(i)-\sum_{j=1}^{j-1} a_{j}^{(i-1)} R(i-j) / E^{(i-1)} \\
a_{i}^{(i)}-k_{(i)} \\
a_{j}^{(l)}-a_{j}^{(j-1)}-k_{(i)} a_{i-j} \\
E^{(n)}=\left(1-k_{i}^{f}\right) E^{(l-1)} \\
a_{j}=a_{j}^{F} \\
A(z)=1-\sum_{k=1}^{p} a_{k} z^{-k}
\end{gathered}
$$

Keterangan :

$R(I)=$ nilai autokorelasi

$E_{()}=$error

(i) $k=$ koefisien pantulan

( $j$ ) $a=$ koefisien Ipc

$\mathrm{A}(\mathrm{z})=$ persamaan koefisien Ipc

Setelah persamaan koefisien didapat, maka selanjutnya adalah mencari akar-akar persamaan koefisien $\mathrm{A}(\mathrm{z})$ dan kemudian dirubah ke dalam perubahan sudut untuk kemudian dihitung nilai formant (Indra, 2016).

Karena koefisen LPC bernilai real, maka akan dilakukan proses pencarian akar yang dimana hanya bagian akar imaginary positif yang dipertahankan dan sudut yang ditentukan oleh persamaan seperti berikut :

$$
\text { ang } z=\sum \tan ^{-1}\left(\frac{\operatorname{Im} r_{k}}{\operatorname{Re} r_{k}}\right)
$$

Dalam persamaan diatas rk adalah akar yang dipertahankan dari polynomial. Frekuensi sudut dalam rad / sampel diubah menjadi $\mathrm{Hz}$ dan lebar pita dari pembentuk dihitung oleh persamaan berikut 


$$
F_{k}=\left(\frac{F_{s}}{2 \pi}\right) \tan ^{-1}\left(\frac{\operatorname{Im} r_{k}}{\operatorname{Re} r_{k}}\right)
$$

Nilai-nilai ini diurutkan dalam urutan menaik. Dan tiga nilai pertama di pilih untuk menjadi nilai 3 forman pertama (Bhore \& Shah, 2015).

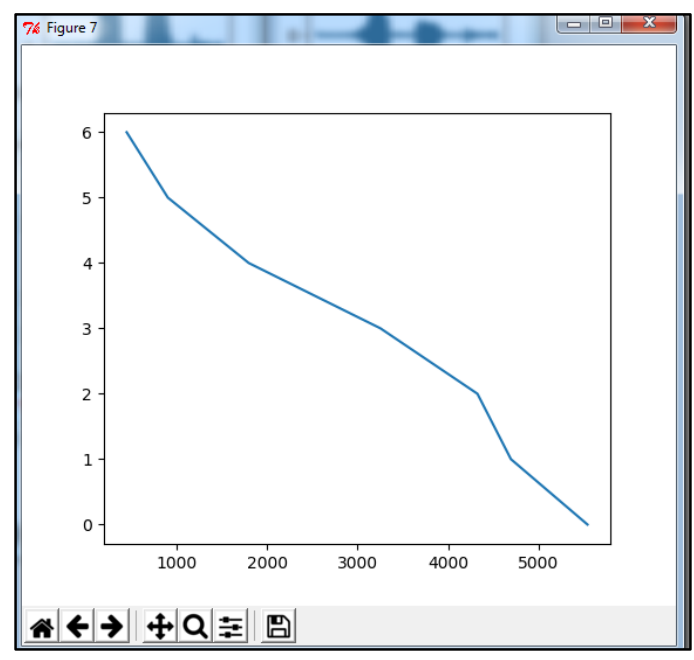

Gambar 8. Sinyal Linear Prediction

\subsection{Standar Suara Forman}

Untuk membedakan vokal suara satu sama lain dapat dilihat melalui nilai forman frekuensi (Russel, 2005). untuk Batasan nilai forman terdapat sebagai berikut Forman 0 atau pitch berada di kisaran $\mathrm{OHz}$ sampai kurang dari $500 \mathrm{~Hz}$ Forman 1 berada di kisaran $500 \mathrm{~Hz}$ sampai kurang dari $1500 \mathrm{~Hz}$ Forman 2 berada di kisaran $1500 \mathrm{~Hz}$ sampai kurang dari $2500 \mathrm{~Hz}$ Forman 3 berada di kisaran lebih dari $2500 \mathrm{~Hz}$ sampai kurang dari $3500 \mathrm{~Hz}$ Forman 4 berada di kisaran lebih dari $3500 \mathrm{~Hz}$ sampai kurang dari $4500 \mathrm{~Hz}$.

\section{HASIL DAN PEMBAHASAN}

Pada penelitian ini telah dilakukan pengujian suara oleh delapan orang. Untuk mendapatkan suara uji, dilakukan perekaman sebanyak sembilan puluh kali yang di mulai pengujian mengucapkan angka satu yang berjumlah sepuluh kali sampai pengucapan angka sembilan sepuluh kali. Jumlah dari suara uji terdapat 720 file wav yang akan dicari nilai formannya.Terdapat nilai forman minimum dan maksimumnya dalam satuan hertz( $\mathrm{Hz})$ untuk suara perempuan dan pria seperti pada Tabel 1.

Tabel 1. Nilai Forman Keseluruhan

\begin{tabular}{|l|c|c|c|c|c|c|c|c|c|c|}
\hline \multirow{2}{*}{$\begin{array}{c}\text { Pengujian } \\
\text { Angka }\end{array}$} & \multicolumn{2}{|c|}{ F0 } & \multicolumn{2}{c|}{ F1 } & \multicolumn{2}{c|}{ F2 } & \multicolumn{2}{c|}{ F3 } & \multicolumn{2}{c|}{ F4 } \\
\cline { 2 - 11 } & MIN & MAX & MIN & MAX & MIN & MAX & MIN & MAX & MIN & MAX \\
\hline Satu & 0 & 487 & 572 & 1486 & 1536 & 2969 & 2676 & 3600 & 3519 & 4922 \\
\hline Dua & 96 & 458 & 592 & 1448 & 1173 & 2890 & 2148 & 3888 & 3234 & 5224 \\
\hline Tiga & 0 & 478 & 263 & 1887 & 1523 & 3072 & 2378 & 3871 & 2766 & 4946 \\
\hline
\end{tabular}




\begin{tabular}{|l|c|c|c|c|c|c|c|c|c|c|}
\hline \multirow{2}{*}{$\begin{array}{c}\text { Pengujian } \\
\text { Angka }\end{array}$} & \multicolumn{2}{|c|}{ FO } & \multicolumn{2}{c|}{ F1 } & \multicolumn{2}{c|}{ F2 } & \multicolumn{2}{c|}{ F3 } & \multicolumn{2}{c|}{ F4 } \\
\cline { 2 - 11 } & MIN & MAX & MIN & MAX & MIN & MAX & MIN & MAX & MIN & MAX \\
\hline Empat & 0 & 495 & 610 & 1477 & 1384 & 2456 & 2214 & 3371 & 3305 & 4682 \\
\hline Lima & 87 & 465 & 587 & 2069 & 1597 & 2873 & 2386 & 3928 & 3412 & 4817 \\
\hline Enam & 0 & 490 & 763 & 1722 & 1416 & 2195 & 2267 & 3502 & 3559 & 4242 \\
\hline Tujuh & 149 & 490 & 549 & 2161 & 1590 & 3112 & 2533 & 4617 & 2985 & 4990 \\
\hline Delapan & 0 & 423 & 515 & 1678 & 940 & 2583 & 2438 & 3384 & 3141 & 4947 \\
\hline Sembilan & 0 & 491 & 504 & 2419 & 1607 & 3358 & 1753 & 3850 & 3376 & 4880 \\
\hline
\end{tabular}

Pada Tabel 1.Terdapat nilai forman keseluruhan dari semua responden yaitu pria dan wanita untuk pengucapan angka satu sampai Sembilan. Untuk pengujian pengucapan angka satu terdapat nilai kisaran angka F0 yaitu dari $0-487 \mathrm{~Hz}$, F1 yaitu dari $572-1486 \mathrm{~Hz}$, F2 yaitu dari $1536 \mathrm{~Hz}-2969 \mathrm{~Hz}$, F3 yaitu dari $2767 \mathrm{~Hz}-3600$ dan F4 yaitu $3519 \mathrm{~Hz}-4922 \mathrm{~Hz}$.

Untuk pengujian pengucapan angka dua terdapat nilai kisaran angka $\mathrm{F} 0$ yaitu dari $96 \mathrm{~Hz}-$ $458 \mathrm{~Hz}$, F1 yaitu dari $592 \mathrm{~Hz}-1448 \mathrm{~Hz}$, F2 yaitu dari $1173 \mathrm{~Hz}-2890 \mathrm{~Hz}$, F3 yaitu dari $2148 \mathrm{~Hz}$ - 3888hZ dan F4 yaitu $3234 \mathrm{~Hz}-5224 \mathrm{~Hz}$.

Untuk pengujian pengucapan angka tiga terdapat nilai kisaran angka $\mathrm{F} 0$ yaitu dari $\mathrm{OHz}-478 \mathrm{~Hz}$ , $\mathrm{F} 1$ yaitu dari $263 \mathrm{~Hz}-1887 \mathrm{~Hz}$, F2 yaitu dari $1523 \mathrm{~Hz}-3072 \mathrm{~Hz}$, F3 yaitu dari $2378 \mathrm{~Hz}-3888 \mathrm{hz}$ dan F4 yaitu $3234 \mathrm{~Hz}-5224 \mathrm{~Hz}$.

Pengucapan angka empat yaitu dari $\mathrm{F} 0$ yaitu dari $\mathrm{OHz}-495 \mathrm{~Hz}, \mathrm{~F} 1$ yaitu $610 \mathrm{~Hz}-1477 \mathrm{~Hz}$, F2 yaitu $1384 \mathrm{~Hz}-2456 \mathrm{~Hz}$, F3 yaitu $2214 \mathrm{~Hz}-3371 \mathrm{~Hz}$ Dan F4 yaitu $3305 \mathrm{~Hz}-4682 \mathrm{~Hz}$.

Pengucapan angka lima yaitu dari $\mathrm{F} 0$ yaitu dari $87 \mathrm{~Hz}-465 \mathrm{~Hz}$, F1 yaitu $584 \mathrm{H}-2069 \mathrm{~Hz}$, F2 yaitu $1597 \mathrm{~Hz}-2873 \mathrm{~Hz}$, F3 yaitu $2386 \mathrm{~Hz}-3928 \mathrm{~Hz}$, F4 yaitu $3412 \mathrm{~Hz}-4817 \mathrm{~Hz}$.

Pengucapan angka enam yaitu dari $\mathrm{F} 0$ dari $0 \mathrm{~Hz}-490 \mathrm{~Hz}$, $\mathrm{F} 1$ yaitu $763 \mathrm{~Hz}-1722 \mathrm{~Hz}$, F2 yaitu $1416 \mathrm{~Hz}-2195 \mathrm{~Hz}$, F3 yaitu $2267 \mathrm{~Hz}-3502 \mathrm{~Hz}$, F4 yaitu $3559 \mathrm{~Hz}-4242 \mathrm{~Hz}$.

Pengucapan angka tujuh yaitu dari F0 yaitu dari $149 \mathrm{~Hz}-490 \mathrm{~Hz}, \mathrm{~F} 1$ yaitu $549 \mathrm{~Hz}-2161 \mathrm{~Hz}$, F2 yaitu $1590 \mathrm{~Hz}-3112 \mathrm{~Hz}$, F3 yaitu $2533 \mathrm{~Hz}-4617 \mathrm{~Hz}$, F4 yaitu $2985 \mathrm{~Hz}-4990 \mathrm{~Hz}$.

Pengucapan angka delapan yaitu dari $\mathrm{F} 0$ yaitu dari $0 \mathrm{~Hz}-423 \mathrm{~Hz}, \mathrm{~F} 1$ yaitu $515 \mathrm{~Hz}-1678 \mathrm{~Hz}$, F2 yaitu $940 \mathrm{~Hz}-2583 \mathrm{~Hz}$, F3 yaitu $2438 \mathrm{~Hz}-3384 \mathrm{~Hz}$, F4 yaitu $3141 \mathrm{~Hz}-4947 \mathrm{~Hz}$.

Pemgucapan angka sembilan yaitu dari $\mathrm{F} 0$ yaitu $0 \mathrm{~Hz}-491 \mathrm{~Hz}, \mathrm{~F} 1$ yaitu $504 \mathrm{~Hz}-2419 \mathrm{~Hz}$, F2 yaitu $1607 \mathrm{~Hz}-3358 \mathrm{~Hz}$, F3 yaitu $1753 \mathrm{~Hz}-3850 \mathrm{~Hz}$, F4 yaitu $3376 \mathrm{~Hz}-4880 \mathrm{~Hz}$.

Tabel 2. Nilai Forman Responden Wanita

\begin{tabular}{|l|c|c|c|c|c|c|c|c|c|c|}
\hline \multirow{2}{*}{ Pengujian Angka } & \multicolumn{2}{|c|}{ F0 } & \multicolumn{2}{c|}{ F1 } & \multicolumn{2}{c|}{ F2 } & \multicolumn{2}{c|}{ F3 } & \multicolumn{2}{c|}{ F4 } \\
\cline { 2 - 11 } & MIN & MAX & MIN & MAX & MIN & MAX & MIN & MAX & MIN & MAX \\
\hline Satu & 185 & 495 & 527 & 1429 & 1516 & 2079 & 3265 & 3449 & 3540 & 4848 \\
\hline Dua & 169 & 485 & 458 & 1434 & 1333 & 2890 & 2844 & 3888 & 3234 & 5224 \\
\hline Tiga & 214 & 476 & 514 & 1460 & 1517 & 2486 & 2874 & 3377 & 3340 & 4629 \\
\hline Empat & 207 & 378 & 671 & 1134 & 1530 & 1843 & 2390 & 3371 & 3328 & 4299 \\
\hline Lima & 214 & 431 & 759 & 1494 & 1497 & 2873 & 2386 & 3482 & 3533 & 4576 \\
\hline Enam & 231 & 415 & 763 & 1480 & 1550 & 2144 & 2267 & 3502 & 3606 & 4162 \\
\hline Tujuh & 344 & 448 & 735 & 1509 & 1590 & 1463 & 2695 & 3190 & 2985 & 4920 \\
\hline
\end{tabular}




\begin{tabular}{|l|c|c|c|c|c|c|c|c|c|c|}
\hline \multirow{2}{*}{ Pengujian Angka } & \multicolumn{2}{|c|}{ F0 } & \multicolumn{2}{c|}{ F1 } & \multicolumn{2}{c|}{ F2 } & \multicolumn{2}{c|}{ F3 } & \multicolumn{2}{c|}{ F4 } \\
\cline { 2 - 11 } & MIN & MAX & MIN & MAX & MIN & MAX & MIN & MAX & MIN & MAX \\
\hline Delapan & 125 & 415 & 675 & 1731 & 2532 & 1821 & 2637 & 3258 & 3141 & 4563 \\
\hline Sembilan & 310 & 472 & 805 & 1474 & 1644 & 2491 & 2657 & 3533 & 3376 & 4691 \\
\hline
\end{tabular}

Pada Tabel 2. Terdapat nilai forman responden wanita yang dimana dari nilai forman ke 0 hingga ke empat mempunyai nilai minimum dan maksimum yang berbeda-beda. Setelah dilakukan pencarian nilai forman dari masing-masing responden, setiap orang mempunyai nilai forman yang berbeda-beda karena karakter suara dan tinggi rendahnya suara seseorang mempengaruhi nilai forman pada orang tersebut.

Pengucapan angka satu yaitu dari F0 yaitu $185 \mathrm{~Hz}-495 \mathrm{~Hz}$, F1 yaitu $527 \mathrm{~Hz}-1429 \mathrm{~Hz}$, F2 yaitu $1516 \mathrm{~Hz}-2079 \mathrm{~Hz}$, F3 yaitu $3265 \mathrm{~Hz}-3449 \mathrm{~Hz}$, F4 yaitu $3540 \mathrm{~Hz}-4848 \mathrm{~Hz}$.

Pengucapan angka dua yaitu dari F0 yaitu $169 \mathrm{~Hz}-485 \mathrm{~Hz}$, F1 yaitu $458 \mathrm{~Hz}-1434 \mathrm{~Hz}$, F2 yaitu $1333 \mathrm{~Hz}-2890 \mathrm{~Hz}$, F3 yaitu $2844 \mathrm{~Hz}-3888 \mathrm{~Hz}, \mathrm{~F} 43234 \mathrm{~Hz}-5224 \mathrm{~Hz}$.

Pengucapan angka tiga yaitu dari F0 yaitu $214 \mathrm{~Hz}-476 \mathrm{~Hz}, \mathrm{~F} 1$ yaitu $514 \mathrm{~Hz}-1460 \mathrm{~Hz}$, F2 yaitu $1517 \mathrm{~Hz}-2486 \mathrm{~Hz}, \mathrm{~F} 3$ yaitu $2874 \mathrm{~Hz}-3377 \mathrm{~Hz}, \mathrm{~F} 4$ yaitu $3340 \mathrm{~Hz}-4629 \mathrm{~Hz}$.

Pengucapan angka empat yaitu dari F0 yaitu $207 \mathrm{~Hz}-378 \mathrm{~Hz}$, F1 yaitu $671 \mathrm{~Hz}-1134 \mathrm{~Hz}$, F2 yaitu $1530 \mathrm{~Hz}-1843 \mathrm{~Hz}$, F3 yaitu $2390 \mathrm{~Hz}-3371 \mathrm{~Hz}$, F4 yaitu $3328 \mathrm{~Hz}-4299 \mathrm{~Hz}$.

Pengucapan angka lima yaitu dari F0 yaitu $214 \mathrm{~Hz}-431 \mathrm{~Hz}$, F1 yaitu $759 \mathrm{~Hz}-1494 \mathrm{~Hz}$, F2 yaitu $1497 \mathrm{~Hz}-2873 \mathrm{~Hz}$, F3 yaitu $2386 \mathrm{~Hz}-3482 \mathrm{~Hz}$, F4 yaitu $3533 \mathrm{~Hz}-4576 \mathrm{~Hz}$.

Pengucapan angka enam yaitu dari F0 yaitu $231 \mathrm{~Hz}-415 \mathrm{~Hz}$, F1 yaitu $763 \mathrm{~Hz}-1480 \mathrm{~Hz}$, F2 yaitu $1550 \mathrm{~Hz}-2144 \mathrm{~Hz}$, F3 yaitu $2267 \mathrm{~Hz}-3502 \mathrm{~Hz}$, F4 yaitu $3606 \mathrm{~Hz}-4162 \mathrm{~Hz}$.

Pengucapan angka tujuh yaitu dari F0 yaitu $344 \mathrm{~Hz}-448 \mathrm{~Hz}$, F1 yaitu $735 \mathrm{~Hz}-1509 \mathrm{~Hz}$, F2 yaitu $1590 \mathrm{~Hz}-1463 \mathrm{~Hz}$, F3 yaitu $2695 \mathrm{~Hz}-3190 \mathrm{~Hz}$, F4 yaitu $2985 \mathrm{~Hz}-4920 \mathrm{~Hz}$.

Pengucapan angka delapan yaitu dari F0 yaitu $125 \mathrm{~Hz}-415 \mathrm{~Hz}$, F1 yaitu $675 \mathrm{~Hz}-1731 \mathrm{~Hz}$, F2 yaitu $2532 \mathrm{~Hz}-1821 \mathrm{~Hz}$, F3 yaitu $2637 \mathrm{~Hz}-3258 \mathrm{~Hz}$, F4 yaitu $3141 \mathrm{~Hz}-4563 \mathrm{~Hz}$.

Pengucapan angka sembilan yaitu dari F0 yaitu $310 \mathrm{~Hz}-472 \mathrm{~Hz}$, $\mathrm{F} 1$ yaitu $805 \mathrm{~Hz}-1474 \mathrm{~Hz}$, F2 yaitu $1644 \mathrm{~Hz}-2491 \mathrm{~Hz}$, F3 yaitu $2657 \mathrm{~Hz}-3533 \mathrm{~Hz}$, F4 yaitu $3376 \mathrm{~Hz}-4691 \mathrm{~Hz}$.

Tabel 3. Nilai Formant Responden Pria

\begin{tabular}{|c|c|c|c|c|c|c|c|c|c|c|}
\hline \multirow{2}{*}{$\begin{array}{c}\text { Pengujian } \\
\text { Angka }\end{array}$} & \multicolumn{2}{|c|}{ F0 } & \multicolumn{2}{c|}{ F1 } & \multicolumn{2}{c|}{ F2 } & \multicolumn{2}{|c|}{ F3 } & \multicolumn{2}{c|}{ F4 } \\
\cline { 2 - 12 } & MIN & MAX & MIN & MAX & MIN & MAX & MIN & MAX & MIN & MAX \\
\hline Satu & 0 & 459 & 527 & 1521 & 1327 & 2671 & 2676 & 3600 & 3519 & 4922 \\
\hline Dua & 96 & 592 & 509 & 1448 & 1173 & 2578 & 2195 & 3447 & 3430 & 4235 \\
\hline Tiga & 0 & 478 & 529 & 1887 & 1523 & 3072 & 2378 & 3871 & 2766 & 4946 \\
\hline Empat & 0 & 495 & 610 & 1477 & 1384 & 2456 & 2214 & 3184 & 3305 & 4682 \\
\hline Lima & 87 & 565 & 387 & 2069 & 1570 & 2582 & 2425 & 3928 & 3412 & 4817 \\
\hline Enam & 0 & 490 & 768 & 1722 & 1416 & 2195 & 2557 & 3182 & 3559 & 4242 \\
\hline Tujuh & 149 & 490 & 349 & 1941 & 1640 & 3112 & 2533 & 4617 & 3276 & 4990 \\
\hline Delapan & 0 & 423 & 515 & 1678 & 1281 & 2583 & 2438 & 3384 & 3298 & 4947 \\
\hline Sembilan & 0 & 491 & 504 & 2419 & 1607 & 3358 & 1753 & 3850 & 3393 & 4880 \\
\hline
\end{tabular}


Pada Tabel 3. Terdapat nilai forman responden pria yang dimana dari nilai forman ke 0 hingga ke 4 mempunyai nilai minimum dan maksimum yang berbeda-beda. Setelah dilakukan pencarian nilai forman dari masing-masing responden, setiap orang mempunyai nilai forman yang berbeda-beda karena karakter suara dan tinggi rendahnya suara seseorang mempengaruhi nilai forman pada orang tersebut. Pada penelitian ini dilakukan pengujian terhadap pria yang berumur 17 tahun hingga 25 tahun. Dimana pada umur tersebut suara pria cenderung mempunyai karakteristik suara yang berat.

Pengucapan angka satu yaitu dari $\mathrm{F} 0$ yaitu $0 \mathrm{~Hz}-459 \mathrm{~Hz}, \mathrm{~F} 1$ yaitu $527 \mathrm{~Hz}-1521 \mathrm{~Hz}$, F2 yaitu $1327 \mathrm{~Hz}-2671 \mathrm{~Hz}, \mathrm{~F} 3$ yaitu $2676 \mathrm{~Hz}-3600 \mathrm{~Hz}$, F4 yaitu $3519 \mathrm{~Hz}-4922 \mathrm{~Hz}$.

Pengucapan angka dua yaitu dari F0 yaitu $96 \mathrm{~Hz}-592 \mathrm{~Hz}, \mathrm{~F} 1$ yaitu $509 \mathrm{~Hz}-1448 \mathrm{~Hz}$, F2 yaitu $1173 \mathrm{~Hz}-2578 \mathrm{~Hz}, \mathrm{~F} 3$ yaitu $2195 \mathrm{~Hz}-3447 \mathrm{~Hz}$, F4 yaitu $3430 \mathrm{~Hz}-4235 \mathrm{~Hz}$.

Pengucapan angka tiga yaitu dari $\mathrm{F} 0$ yaitu $0 \mathrm{~Hz}-478 \mathrm{~Hz}$, $\mathrm{F} 1$ yaitu $529 \mathrm{~Hz}-1887 \mathrm{~Hz}$, F2 yaitu $1523 \mathrm{~Hz}-3072 \mathrm{~Hz}, \mathrm{~F} 3$ yaitu $2378 \mathrm{~Hz}-2871 \mathrm{~Hz}$, F4 yaitu $2766 \mathrm{~Hz}-4946 \mathrm{~Hz}$.

Pengucapan angka empat yaitu dari $\mathrm{F} 0$ yaitu $\mathrm{OHz}-495 \mathrm{~Hz}, \mathrm{~F} 1$ yaitu $610 \mathrm{~Hz}-1477 \mathrm{~Hz}$, F2 yaitu $1384 \mathrm{~Hz}-2456 \mathrm{~Hz}, \mathrm{~F} 3$ yaitu $2214 \mathrm{~Hz}-3184 \mathrm{~Hz}$, F4 yaitu $2766 \mathrm{~Hz}-4946 \mathrm{~Hz}$.

Pengucapan angka lima yaitu dari $\mathrm{F0}$ yaitu $87 \mathrm{~Hz}-565 \mathrm{~Hz}$, $\mathrm{F} 1$ yaitu $387 \mathrm{~Hz}-2069 \mathrm{~Hz}$, F2 yaitu $1570 \mathrm{~Hz}-2582 \mathrm{~Hz}$, F3 yaitu $2425-3928 \mathrm{~Hz}$, F4 yaitu $3412 \mathrm{~Hz}-4817 \mathrm{~Hz}$.

Pengucapan angka enam yaitu dari $\mathrm{F} 0$ yaitu $0 \mathrm{~Hz}-490 \mathrm{~Hz}, \mathrm{~F} 1$ yaitu $768 \mathrm{~Hz}-1722 \mathrm{~Hz}$, F2 yaitu $1416 \mathrm{~Hz}-2195 \mathrm{~Hz}, \mathrm{~F} 3$ yaitu $2557 \mathrm{~Hz}-3182 \mathrm{~Hz}$, F4 yaitu $3559 \mathrm{~Hz}-4242 \mathrm{~Hz}$.

Pengucapan angka tujuh yaitu dari F0 yaitu $149 \mathrm{~Hz}-490 \mathrm{~Hz}, \mathrm{~F} 1$ yaitu $349 \mathrm{~Hz}-1941 \mathrm{~Hz}$, F2 yaitu $1640 \mathrm{~Hz}-3112 \mathrm{~Hz}$, F3 yaitu $2533 \mathrm{~Hz}-4617 \mathrm{~Hz}$, F4 yaitu $3276 \mathrm{~Hz}-4990 \mathrm{~Hz}$.

Pengucapan angka delapan yaitu dari $\mathrm{F} 0$ yaitu $\mathrm{OHz}-423 \mathrm{~Hz}$, $\mathrm{F} 1$ yaitu $515 \mathrm{~Hz}-1678 \mathrm{~Hz}$, F2 yaitu $1281 \mathrm{~Hz}-2583 \mathrm{~Hz}$, F3 yaitu $2438 \mathrm{~Hz}-3384 \mathrm{~Hz}$, F4 yaitu $3298 \mathrm{~Hz}-4947 \mathrm{~Hz}$.

Pengucapan angka sembilan yaitu dari $\mathrm{F} 0$ yaitu $0 \mathrm{~Hz}-491 \mathrm{~Hz}$, $\mathrm{F} 1$ yaitu $504 \mathrm{~Hz}-2419 \mathrm{~Hz}$, F2 yaitu $1607 \mathrm{~Hz}-3358 \mathrm{~Hz}$, F3 yaitu $1753 \mathrm{~Hz}-3850 \mathrm{~Hz}$, F4 yaitu $3393 \mathrm{~Hz}-4880 \mathrm{~Hz}$.

\section{KESIMPULAN}

Berdasarkan penelitian mengenai sistem penentuan kualitas suara berdasarkan forman frekuensi yang telah dilakukan, diperoleh kesimpulan sebagai berikut :

1. Sistem yang dibangun dapat digunakan untuk mengenali suara berupa angka dengan pengumpulan data latih dengan kondisi kebisingan ruangan dari $30 \mathrm{~dB}$ sampai $90 \mathrm{~dB}$.

2. Terdapat 2700 data suara uji dengan durasi perekaman suara dilakukan selama 1 detik. Berdasarkan hasil pengujian nilai forman yang diperoleh untuk F0 kisaran 0-423, nilai forman F1 kisaran 572-1678, nilai forman F2 kisaran 1536-2583, nilai forman F3 kisaran 2676-3384, nilai forman F4 kisaran 3519-4947. 


\section{DAFTAR RUJUKAN}

Bhaskoro, S. B., \& D, A. (2012). Aplikasi Pengenalan Gender Menggunakan Suara. Seminar Nasional Aplikasi Teknologi Informasi (SNATI 2012), (pp. 16-23).

Bhore, S., \& Shah, M. (2015). A Comparative Study of Formant Estimation. International Journal of Advanced Research in Electronics and Communication Engineering (IJARECE), 4(12), 2879-2882.

Devi , L., Erwin, \& Surbakti, A. (2017). Analisa Pengaruh Penyakit Flu Dan Batuk Terhadap Suara Penderita Dengan Menggunakan Komputer. Retrieved from Repository University of Riau: repository.unri.ac.id

Dewi, I. A., Zulkarnain, A., \& Aprilia , A. (2018). Identifikasi Suara Tangisan Bayi menggunakan Metode LPC dan Euclidean Distance. ELKOMIKA: Jurnal Teknik Energi Elektrik, Teknik Telekomunikasi, \& Teknik Elektronika, 6(1), 153-164.

Indra, T. P. (2016). Pengindentifikasian Suara Tinggi Dan Rendah Pada Pria Dan Wanita Ditinjau Dari Pitch Dan Formant Menggunakan Metode Support Vector Machine. Retrieved from Unikom Repository: https://repository.unikom.ac.id/294/

Nurhasanah, Y. I., Zulkarnain, A., \& Permatasari, D. (2017). Pengenalan Pembicara untuk Menentukan Gender Menggunakan Metode MFCC dan VQ. MIND (Multimedia, Artificial Intelligence, Networking, Database) Journal, 2(1), 34-47.

Permana, I. S., Nurhasanah, I. Y., \& Zulkarnain, A. (2018). Implementasi Metode Mfcc Dan Dtw Untuk Pengenalan Jenis Suara Pria Dan Wanita. MIND (Multimedia, Artificial Intelligence, Networking, Database) Journal, 3(1), 49 - 63.

Rabiner, L., \& Juang, B.-H. (1993). Fundamentals of speech recognition. New Jersey: PrenticeHall, Inc.

Russel, K. (2005). General Phonetics. Retrieved from home.cc.umanitoba.ca.

Umar, R., Sunardi , S., \& Gustafi, M. F. (2019). Analisis Statistik Manipulasi Pitch Suara Menggunakan Audio Forensik Untuk Bukti Digital. Jurnal Mobile and Forensics (MF), $1(1), 1-12$. 